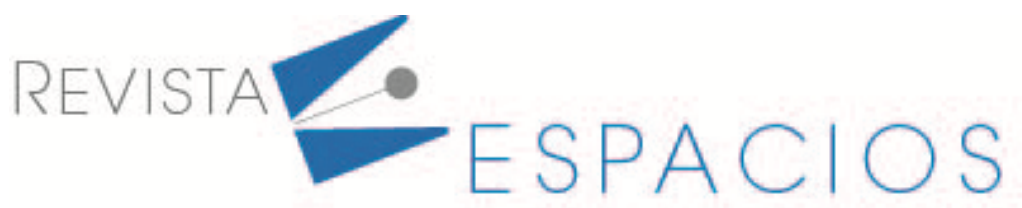

\title{
Factors associated with the success of the cultivation of Tectona grandis Linn F. using the Mic-Mac technique
}

\author{
Factores asociados al éxito del cultivo de Tectona grandis Linn F. mediante la técnica Mic- \\ Mac
}

\author{
MARTELO, Raúl J. ${ }^{1}$ \\ BASTIDAS, Maira ${ }^{2}$ \\ TOVAR, Luis $\mathrm{C}^{3}$
}

\begin{abstract}
The objective was to determine the factors associated with the success of teak crop production (Tectona grandis Linn F.). Regarding the methodology, the research was mixed with a sequential exploratory design. The documentary review was used as a data collection technique, and the Micmac technique was used to analyze the data. As a result, five key factors (fertilization, planting techniques, spacing, climate, and site), four determining factors, an autonomous factor, and an output factor were found.

key words: forestry, forest ecology, teak, agroforestry

Resumen

El objetivo fue determinar los factores asociados al éxito de la producción de cultivos de teca (Tectona grandis Linn F.). Respecto a la metodología, la investigación fue mixta con un diseño exploratorio secuencial. Se utilizó la revisión documental como técnica de recolección de información y la técnica Micmac para analizar los datos. Como resultado, se encontraron cinco factores clave (fertilización, técnicas de siembra, espaciamiento, clima y sitio), cuatro factores determinantes, un factor autónomo y un factor de salida.

Palabras clave: silvicultura, ecología forestal, teca, agroforestería
\end{abstract}

\section{Introduction}

Teak (Tectona grandis Linn F.), is one of the most planted species in the world. Considered the king of wood, it belongs to the Lamiaceae family, it is a fast-growing leafy tree that can reach more than 30 meters in height under favorable conditions (Ball et al., 1999). Its wood is appreciated worldwide for its appearance, quality and durability (Rosamah, et al., 2020). Its natural oil and silicate concentration allow it hardness and resistance to attack by insects and bacteria, fire and acids (Aguirre, 2013). As it is a luxury and high quality product, it is used in the construction of houses and furniture, among others (Rodrigues, 2019), which results in it having a high economic value (Poningsih, 2017). However, despite its price, it has great public demand and its

\footnotetext{
${ }^{1}$ Professor. Faculty of Engineering. University of Cartagena. rmartelog1@unicartagena.edu.co

${ }^{2}$ Systems Engineer. Faculty of Engineering. University of Cartagena. maira2121@gmail.com

3 Professor. Faculty of Engineering. University of Cartagena. Itovarg@unicartagena.edu.co
} 
commercialization stands out in the countries of the Asian continent, where internal production does not supply its own industry, and they are forced to import this type of fine wood (Pozo, 2013).

It could be said that teak cultivation is a good option for those who wish to invest in forestry projects. Several institutions estimate that the return on investment of this species is $15 \%$ for a business with average profitability, which makes it an attractive and promising market for its functionality and commercial stability (Salazar, 2016). However, despite its rapid percentage growth, the initial investment is high and, like other forestry projects, it has a long maturation period (García et al., 2011), that is, there is a long time interval between initial investment and productive results.

On the other hand, the situations that may arise during production are diverse, which is why it is necessary to carry out a study that allows knowing the factors and risks associated with agroforestry plantations, in order to have a reference and be able to decide if it is viable to invest in this sector (Phimmavong et al., 2019). In the literature, no studies were found on the factors associated with the success of teak cultivation, however, some manuals (Fonseca, 2004), methods (Masilamani et al., 2017) and other studies (Palakit et al., 2019), Walters \& Lyons (2016), Roshetko et al. (2016) and Suwannapinant (2001), discussed aspects and influential variables in the cultivation of this species, which allowed determining a list of factors associated with the success of teak cultivation.

Similarly, the aforementioned authors demonstrated that the cultivation and management of teak plantations is complex due to the variations in the environmental, social, and economic conditions of each country. In addition, the factors that constitute and influence these plantations must be known to avoid losses. Therefore, the present study aims to determine the factors associated with the success of teak cultivation, through a documentary review and a structural analysis with the MICMAC technique, and classify them as keys, determinants, autonomous and exit.

\section{Methodology}

For the development of this research, a systematic review was carried out on teak cultivation, characteristics of the teak tree, forest management, forestry, among other concepts. The research was of a mixed type with a sequential exploratory design, because, firstly, qualitative data was collected and analyzed, followed by the collection and analysis of quantitative data (Hernández et al., 2014). In this case, the factors that directly and indirectly intervene in the success of teak cultivation were studied, which will allow expanding the results found in the literature on this topic. The information collection was through the documentary review and for its analysis, the MICMAC technique was applied, which allows identifying the variables in this case, motor and dependent factors (key factors), applying matrix multiplication to a structural matrix, to study the diffusion of the impacts produced by each factor (Sarría et al. 2009).

\subsection{Method procedure}

\subsubsection{Documentary review}

A systematic review was carried out on topics related to community teak forestry, growth and yield of teak plantations, management of teak forests, seeding, fertilization and germination of teak and applications of teak, among other related topics, where authors such as Fonseca (2000), Fonseca (2004), Velasteguí (2010), and Villacis (2019) were taken into account. 


\subsubsection{Selection of factors}

Once the documentary review was completed, the most common factors that were associated with obtaining excellent specimens of teak tree were selected according to the literature, resulting in a list that embraced all the factors mentioned, which served as input for the application of the MICMAC technique.

\subsubsection{Application of the Micmac technique}

In order to study the diffusion of the impacts produced by each factor, in addition to ranking them, the MICMAC technique was used, which describes a system through a matrix that links its components, identifies influencing and dependent factors, thereby highlighting the factors keys of a system (Arango \& Cuevas, 2015). This technique has wide applications in determining key factors and variables in different areas. Martelo et al. (2017) determined the key factors for school dropout and in Martelo et al. (2018) used this technique to determine the key variables in a program proposal for public universities and in Bastidas et al. (2018) was used to determine the factors for learning the English language.

Due to the usefulness of this technique to determine key variables and factors, it was decided to use this technique in this study. For its application, the Softprosp web platform was used, in which the matrix of influence and direct dependence was drawn up with the list of factors found in the documentary review, and then the matrix was evaluated with the help of 5 experts in forestry and cultivation of teak. The consensus in the valuation of the matrix, allowed to carry out the calculations that finally showed the factors associated with the success of teak cultivation.

\subsubsection{Report on the results obtained}

The calculations with the application of the Micmac technique done, a report was obtained where the factors associated with the success of teak cultivation are presented, the location of each factor and the relationship between them, which reveals the most important factors to achieve a cultivation. successful teak.

\section{Results}

In this session the results obtained are presented, after applying the proposed methodology: first, the results of the documentary review, allowed us to find the most relevant factors that must be taken into account in order to be successful in teak cultivation. Eleven factors were found, which are shown in Table 1.

As seen in Table 1, the first column corresponds to the factor number, the second column corresponds to the short name, the third column corresponds to the long name and finally the factor description. In this way, the first factor of short name, Site, long name, Site and description: Place where the trees will be planted, this factor includes the selection of the site and its characteristics (altitude, seasons, structure, fertility, pH, acidity saturation, among other characteristics). This list of factors was the input to apply the MICMAC technique, for which five experts in teak cultivation filled the matrix with direct influence. This matrix is filled with values from 0 to 4, where 0 : there is no relationship, 1: relationship is weak, 2: moderate relationship, 3: strong relationship and 4: potential relationship. The results of filling the matrix evidenced the values observed in Figure 1. 
Table 1

List of factors

\begin{tabular}{|c|c|c|c|}
\hline $\mathbf{N}^{\circ}$ & Short name & Long name & Description \\
\hline 1 & Site & Site & $\begin{array}{l}\text { Place where trees will be planted, this factor includes site selection } \\
\text { and characteristics. }\end{array}$ \\
\hline 2 & Sowing & Planting techniques & Techniques used for planting (seed, heels, transplant) \\
\hline 3 & Climate & Climate & Climatic condition (Tropical, warm and humid) \\
\hline 4 & Space & Spacing & Distance between trees \\
\hline 5 & Seed & Seed & seed characteristics (provenance) \\
\hline 6 & Thinning & Thinning & Excessive fruit reduction process to moderate tree load. \\
\hline 7 & Pruning & Pruning & $\begin{array}{l}\text { Reduction of lateral branches to optimize the quality and } \\
\text { appearance of the wood. }\end{array}$ \\
\hline 8 & Fertilization & Fertilization & $\begin{array}{l}\text { Contribution of nutrients so that the plant is productive in quantity } \\
\text { and quality. }\end{array}$ \\
\hline 9 & Weather & Atmospheric weather & $\begin{array}{l}\text { State of the atmosphere at a given time and place defined by } \\
\text { meteorological variables. }\end{array}$ \\
\hline 10 & Control & $\begin{array}{l}\text { Control of pests and } \\
\text { diseases }\end{array}$ & Control pests and diseases in scoring. \\
\hline 11 & Floor & Floor & Soil characteristics, soil preparation. \\
\hline
\end{tabular}

Source: Authors

Figure 1

Direct influence matrix

\begin{tabular}{|c|c|c|c|c|c|c|c|c|c|c|c|c|}
\hline & Climate & Control & Space & Fertilization & Pruning & Thinning & Seed & Sowing & Site & Floor & Weather & D.I. \\
\hline Climate & 0 & 3 & 2 & 3 & 0 & 0 & 2 & 3 & 3 & 1 & 3 & 20 \\
\hline Control & 1 & 0 & 3 & 3 & 0 & 0 & 0 & 3 & 1 & 3 & 1 & 15 \\
\hline Space & 0 & 3 & 0 & 3 & 3 & 3 & 0 & 3 & 3 & 3 & 0 & 21 \\
\hline Fertilization & 3 & 3 & 3 & 0 & 3 & 3 & 3 & 1 & 3 & 3 & 3 & 28 \\
\hline Pruning & 3 & 2 & 3 & 3 & 0 & 1 & 0 & 2 & 3 & 2 & 0 & 19 \\
\hline Thinning & 3 & 2 & 3 & 3 & 3 & 0 & 2 & 3 & 3 & 1 & 2 & 25 \\
\hline Seed & 3 & 0 & 0 & 3 & 3 & 3 & 0 & 3 & 3 & 3 & 0 & 21 \\
\hline Sowing & 3 & 3 & 3 & 1 & 0 & 3 & 3 & 0 & 3 & 1 & 3 & 23 \\
\hline Site & 3 & 2 & 3 & 3 & 0 & 0 & 3 & 3 & 0 & 0 & 2 & 19 \\
\hline Floor & 0 & 3 & 3 & 3 & 3 & 0 & 1 & 3 & 3 & 0 & 1 & 20 \\
\hline Weather & 3 & 3 & 0 & 0 & 0 & 0 & 0 & 0 & 0 & 1 & 0 & 7 \\
\hline D.D. & 22 & 24 & 23 & 25 & 15 & 13 & 14 & 24 & 25 & 18 & 15 & 218 \\
\hline
\end{tabular}


As observed in the influence relationship matrix presented in Figure 1, the climate factor has a strong direct influence relationship (3), with the Control factor, that is, the climate has a strong influence on pest control and diseases. In the case of the relationship of influence of the Climate factor and the Space factor, the experts rated it as moderate (2), that is, that climate influences spacing moderately. Regarding the relation of the Climate factor with the Fertilization factor, the influence relation was valued as strong (3). And in this way, Figure 1 describes the relationship between each factor. From the evaluation of the direct influence matrix above, the direct influence plane resulted, which is divided into four quadrants that classify the factors as: keys, determined, autonomous or results.

The direct influence plane is made up of four zones or quadrants, where in the first, also called the Conflict Zone (pink quadrant), the key factors are located, in the second, Power Zone (yellow quadrant), the determining factors In the third, Autonomous Zone (blue quadrant), the autonomous factors, and in the fourth quadrant, Output Zone (green quadrant), the outcome factors are located. Figure 2 shows that when applying the MICMAC technique, the results described below were obtained:

Figure 2

Plane of direct influence

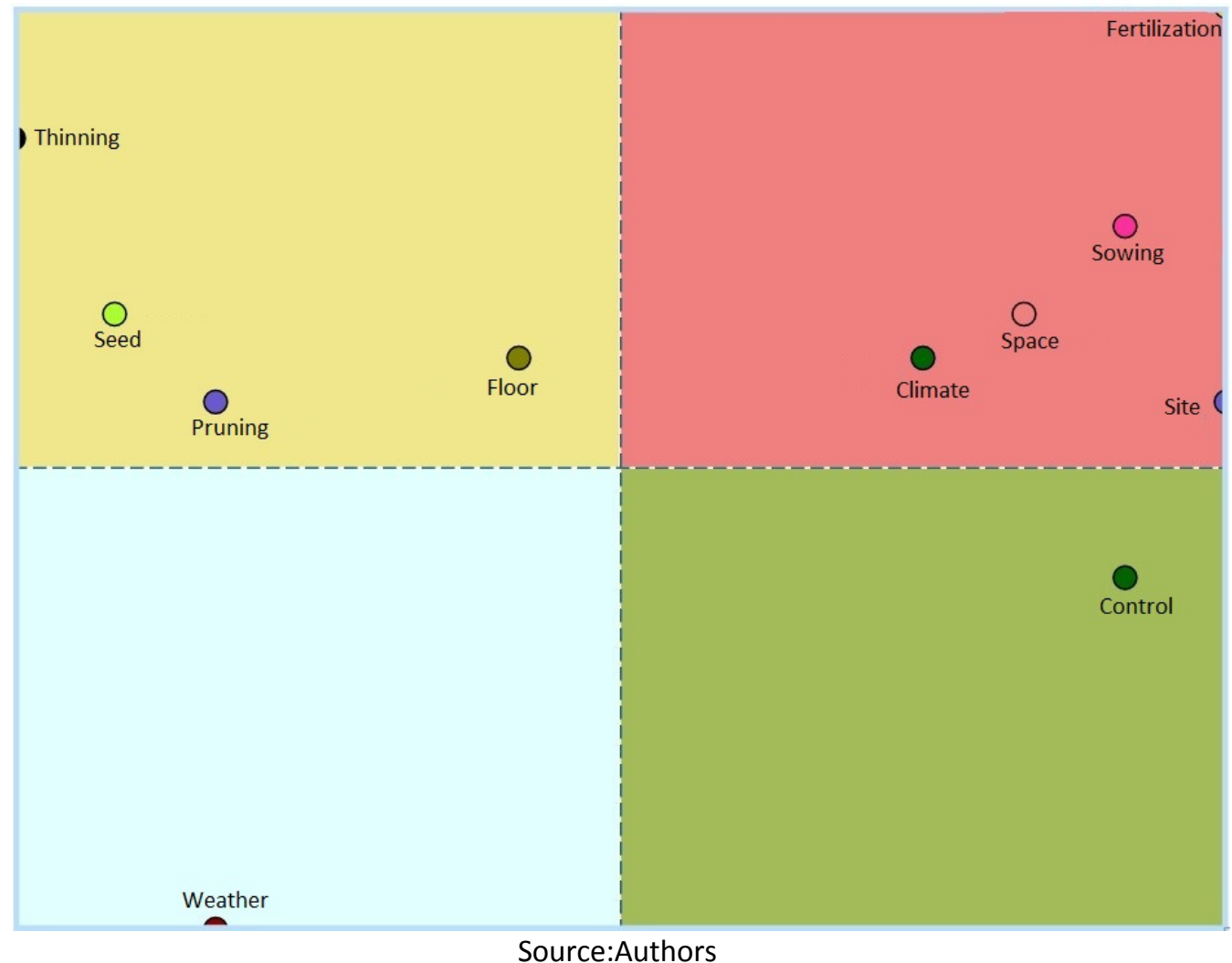

Conflict zone: in this zone the key factors are located, that is, critical factors for the success of teak crop production. As Figure 2 shows, five (5) factors were located in this area: Fertilization, Planting, Space, Weather and Site. These results are in agreement with various studies that affirm that for a teak producer to achieve a good crop, he must take into account some of these five factors as the most important to take into account, as well as other factors located in the power zone. The importance of each of these five factors is explained below.

Fertilization: it makes sense that this factor is located in this area, because teak responds in a varied way to fertilization in the plantation area. With the application of $\mathrm{N}, \mathrm{P}, \mathrm{K}$ or Ca, to soils with low fertility, the wood develops favorably, improving the color, vitality and growth of the tree (Fonseca, 2000), while, if no corrections 
are applied to soils with low fertility, nutritional insufficiencies such as chlorosis, necrosis and perhaps the death of trees are manifested (Kumar 2005).

Sowing (Planting techniques): This factor is key, because, depending on the technique and the material used for planting, the results will be. Artificial teak planting can be done manually or using some degree of mechanization. Seeds, stumps and rooted cuttings are used, among others, however, it is best to use seedlings from certified seeds of genetic quality, because sowing seeds directly in the soil has high mortality and little growth (Fonseca, 2004). The recommended time to plant is in rainy weather and after a month of planting, if the survival is less than $80 \%$, it can be replanted.

Space (Spacing): The location of this factor in the conflict zone is adequate, because spacing plays an important role in the growth and quality of wood. If the spacing is wide, although the diameter increases, the mass is negatively impacted, because the canopy (tree roof) does not close properly, clean shafts are not obtained and malformations appear.

Authors such as Chaves and Fonseca (1991) and Camacho-Linton et al., (2013), register very different spacings, even in regions with a long history in teak cultivation, and also affirm that this factor depends on the use that is being made of it. to give the wood. In this sense, to produce firewood and charcoal, it is recommended that the spacing between plants should be $1.5 \times 1.5 \mathrm{~m}$, while, for wood for sawing purposes, the standard spacing is 3.0 x 3.0 m. Other authors such as Keogh (1987) and Chavarría and Quirós (1985), recommend spacings of 2.5m between plants and $2.0 \mathrm{~m}$ between rows, for a density of 2000 trees per hectare, and to obtain sawwood, they recommend a spacing of $2.0 \times 2.0 \mathrm{~m}, 2.0 \times 2.5 \mathrm{~m}$ or $2.3 \times 2.3 \mathrm{~m}$, with a density of $1900-2000-2500$ trees, respectively.

Climate: the location of this factor in the conflict zone is consistent with its importance, because, in order to produce quality wood, the climatic conditions must be appropriate. The temperature should range from $5^{\circ} \mathrm{C}$ to $30{ }^{\circ} \mathrm{C}$. This species does not develop properly in temperatures above $30^{\circ} \mathrm{C}$. In this sense, if the climate is not adequate, the crop could fail, this is because frosts negatively affect the crop and high temperatures limit growth or destroy the crop due to water stress (Torres, 1982).

On the other hand, this species needs a minimum annual rainfall of $1000 \mathrm{~mm}$ of rain, a maximum of $1800 \mathrm{~mm}$ for wood production and a minimum of $760 \mathrm{~mm} /$ year, for the survival of the species (Chaves and Fonseca, 1991). Regarding humidity, different conditions are required, according to the provenance of the species (Villacis, 2019). On the other hand, teak reaches its maximum development and height in hot and humid tropical climates, with precipitation between 1250 and $2500 \mathrm{~mm}$ per year, with marked dry seasons for periods of 3 to 5 months (Palakit et al., 2019).

Site: Selection of geographic location is of utmost importance to be successful in cultivation. This is one of the factors that was located in the conflict zone, because important aspects such as yield, growth and the age at which the species blooms, vary according to the geographical location where the species has been planted. To select quality sites, the Site Index (IS) is used, which allows knowing the capacity of a site for the production of forests in a certain time, through the response of factors such as: climatic, edaphic, topographic and biotic. (Chaves and Fonseca, 1991). Sites with fertile, drained and neutral soils with depths greater than $80 \mathrm{~cm}$ are recommended, because flat sites with superficial layers of sand, hard lateritic soils and deep dry soils limit the growth of the species (Chávez, 1989).

Power zone (yellow quadrant): determining factors are located in this zone, that is, factors that represent an input for the system, which is why they require attention in order to influence the success of teak cultivation. The plan shows that five (4) factors were located in this area: Seed, Thinning, Pruning and Soil. These results show that these factors, added to those of the conflict zone, determine the success of teak cultivation, that is, 
they are the factors that need more attention to achieve the best production of quality teak according to the objective of the producer. The importance of each of these factors is presented below.

Seed: the results locate this factor in the power zone, which is correct, because characteristics such as the straightness of the trunk, depend on the origin of the seed. Studies show that, for quality, seeds from humid places are more recommended. On the other hand, characteristics such as the maximum height reached by the trees are a consequence of the site conditions and have low dependence on the seed (Fonseca, 2004). It is important to keep in mind that any wrong selection of seedlings can have a negative impact on the entire plantation and these will only be reflected after 10 years (Franco, 2015).

Thinning: the location of this factor in the power zone indicates that thinning must be applied in an appropriate manner and at the right time. This operation allows to distribute the growth potential to improve the quality of the surplus trees. If this operation is slow to take place, the growth slows down or stops, however, if it is carried out prematurely or intensively, the trees tend to produce lateral branches and superficial shoots, which is inconvenient, because the Growth is not concentrated in the trunk, for this reason this is one of the determining factors for the success of the crop.

Pruning: this factor is decisive because if applied at an early age, it favors the warmth of the wood. This operation minimizes the size of the tree canopy and the lateral branches to improve the quality and appearance of the wood. It should be done flush with the trunk, and be careful not to cause injuries to the trunk, because it will be reflected later (Castro \& Oprandi, 2018).

Soil: this factor is important because, depending on its state and conditions, it determines the growth and development of the plant, it is considered as a limiting factor if it is shallow, flat, flooded or poorly drained. In soils with concentrations between 150 and 160 ppm of Potassium, 15 ppm of Manganese (Mn), 2 ppm of zinc $(\mathrm{Zn})$ and $10 \mathrm{cmol} / \mathrm{I}$ of $\mathrm{Ca}+\mathrm{Mg}+\mathrm{K}$ for every $100 \mathrm{gr}$ of soil in the first $10 \mathrm{~cm}$ depth, are considered recommended to achieve a good crop; Similarly, soils with acid saturation percentages less than $5.8 \%$ and calcium saturation percentages greater than 67\% (Alvarado \& Fallas, 2004). It is essential that ground preparation activities are carried out to achieve maximum performance (Roshetko, et al., 2016).

Autonomous zone (blue quadrant): factors that are poorly motorized and not very dependent are located in this area, that is, factors that are difficult to control and, therefore, unpredictable in the system. The plan shows that one (1) factor was located in this area: Weather. This factor is autonomous and depends on various meteorological variables such as temperature, pressure, wind, solar radiation, humidity and precipitation. It is important to differentiate climate weather, since the latter refers to the average atmospheric conditions that characterize a place.

Weather: it makes sense that this factor has been located in the autonomous zone because there is no control over this factor, however, it maintains a strong influence relationship with the Climate factor, because the climate is the weather that It prevails in one place for many years, that is, if we study the weather that it usually does in the same place over several years, we can know the climate of that place.

Exit area (yellow quadrant): in this area are the factors that are the result, that is, factors that are a consequence of the way in which the key, determining and autonomous factors act. The results on the map show that one (1) factor was located in this sector: Control (Control of pests and diseases). In other words, as the factors of conflict zones and power are worked on, they will be reflected in the control of pests and diseases.

Pest and disease control: this factor that was located in the exit zone indicates that, according to the behavior of other factors, it will be the result of this, the above agrees with what was found in the literature, where it is stated that, depending on the site, soil preparation and fertilization, if teak develops in good conditions, its 
properties and oils, make it resistant to fungi and insects and presents few pests and diseases (Velasteguí et al., 2010). However, sometimes it is affected by diseases caused by fungi or other organisms, in the same way, it presents rot and decomposition of the root, which only seriously affects in very humid, poor places with low fertility soils (Fonseca, 2004).

\section{Conclusions}

The application of the Micmac technique to carry out the structural analysis, made it possible to show the relationships between each of the factors, thereby classifying the key, determining, autonomous and output factors. This study allowed to conclude that the origin of the seed by itself does not determine the successful production of the crop, instead the geographical location, as well as the climate where it is planted, has a great influence on the development of the plant. In addition, depending on the use that will be given to the wood, the spacing must be, likewise, depending on the place where it is going to be planted, the seed must be selected taking into account the place of origin of the same. The factors together: soil preparation, fertilization, spacing, planting material and the site, will determine the success of teak cultivation, however, all the factors found must be taken into account. On the other hand, because the key factors vary according to the geographical location because the climatic conditions and soil characteristics are different in each place, this factor is the most prominent among all those found.

\section{Bibliographic references}

Aguirre, N. (2013). Métodos de desinfección de sustrato para el control de damping-off en semillero de teca (Tectona grandis linn f.), bajo invernadero en la empresa seragroforest. Thesis, Escuela Superior Politécnica de Chimborazo, Santo Domingo de los Tsátilas.

Alvarado, A., \& Fallas, J. (2004). La saturación de acidez y el encalado sobre el crecimiento de la teca (Tectona grandis Lf) en suelos ácidos de Costa Rica. Agronomía Costarricense, 28(1), 81-87.

Arango, X., \& Cuevas, V. (2015). Método de análisis estructural: matriz de impactos cruzados multiplicación aplicada a una clasificación (MICMAC). In K. Sáenz, \& G. Tamez, MÉTODOS Y TÉCNICAS CUALITATIVAS Y CUANTITATIVAS APLICABLES A LA INVESTIGACIÓN EN CIENCIAS SOCIALES (págs. 393-417). México: TIRANT HUMANIDADES.

Ball, J., Pandey, D., \& Hirai, S. (1999). Global overview of teak plantation. Regional Seminar on site, technology and Productivity of Teak plantations, (pp. 1-14). Chiang Mai.

Bastidas, M., Jaramillo, J., Martelo, R., Meza-Andrade, L., \& Jiménez, M. (2018). Definition of an Action Plan for Learning English. Contemporary Engineering Sciences, 11(41), 2023-2031.

Camacho-Linton, A., Ramírez-Maldonado, H., de los Santos-Posadas, H., \& Zamudio Sánchez, F. (2013). Yield tables for teak (Tectona grandis L.) in the State of Campeche. Revista Mexicana de Ciencias Forestales, 4(19), 92-101.

Castro, C., \& Oprandi, G. (2018). Manejo silvopastoril en montes de chañar. Voces y Ecos, 19(39), 48-51.

Chavarría, M., \& Quirós, S. (1985). Tectona grandis. Technical report , FAO, San José.

Chaves, S. (1989). Factores limitantes en el crecimiento de teca (Tectona grandis L. f) en la zona de Puntarenas, Costa Rica. Guía Agropecuaria, 7(14), 64-66.

Chávez, E., \& Fonseca, W. (1991). Teca, especie de árbol de uso múltiple en América Central. Turrialba: CATIE. 
Fonseca, W. (2000). La aplicación de fertilizantes químicos en Tectona grandis Linn. f. en Guanacaste, Costa Rica. San José: Consejo Nacional de Rectores.

Fonseca, W. (2004). Manual para productores de teca (Tectona grandis L. f) en Costa Rica. Heredia.

Franco, D. (2015). Asesoría y acompañamiento en el cultivo de teca en la finca La Guadalupana en Turbo, Antioquia. Doctoral thesis, Corporación Universitaria Lasallista, Turbo.

García, X., Rodríguez, B., \& Islas, J. (2011). Evaluación financiera de plantaciones forestales de caoba en Quintana Roo. Revista mexicana de ciencias forestales, 2(7), 7-26.

Hernández, R., Fernández, C., \& Baptista, P. (2014). Metodología de la investigación. México: Mc Graw Hill Education.

Keogh, R. (1987). The Care and management of teak (Tectona grandis L.f.) Plantations. Technical report, Universidad Nacional, Heredia.

Kumar, B. (2005). Sustainable teak plantations in the tropics: the question of nutrient management. Kerala Forest Research Institute, Kerala.

Martelo, R., Bastidas, M., \& Gómez, J. (2018). Determination of key variables for the program proposal to address aspiring undergraduate programs in public universities. Contemporary Engineering Sciences, 11(15), 707-717.

Martelo, R., Jiménez-Pitre, I., \& Villabona-Gómez, N. (2017). Determinación de factores para deserción de estudiantes en pregrado a través de las técnicas Iluvia de ideas y MICMAC. Revista Espacios, 38(20), 24-32.

Masilamani, P., Selvam, S., Albert, V., \& Govindaraj, M. (2017). Effect of Different Methods of Lifting and Stumping of Teak (Tectona grandis Linn. f.) Seedlings on Stump Quality and its Economic Analysis. Indian Journal of Forestry, 40(2), 139-142.

Palakit, K., Lumyai, P., \& Duangsathaporn, K. (2019). Influence of Climate on the Growth of Teak (Tectona grandis Linn. f.) at a Non-native Distributed Site in Northeastern Thailand. CHIANG MAI JOURNAL OF SCIENCE, 46(6), 1113-1128.

Phimmavong, S., Maraseni, T., Keenan, R., \& Cockfield, G. (2019). Financial returns from collaborative investment models of Eucalyptus agroforestry plantations in Lao PDR. Land Use Policy, 87. doi:10.1016/j.landusepol.2019.104060

Poningsih, P. (2017). iseño del sistema experto para analizar enfermedades en Plant Teak usando Forward Chaining. Revista Internacional de Investigación de Inteligencia Artificial, 1(1), 11-15.

Pozo, p. (2013). Investigación del Mercado Chino para la exportación de Teca en trozas y muebles. Thesis, Universidad Internacional de Guayaquil, Guayaquil.

Rodrigues, L. (2019). Gujarat ornamental furniture: artisans, techniques, skills and global markets during the nineteenth century. In Knowledge and the Indian Ocean (pp. 113-136). Cham: Palgrave Macmillan.

Rosamah, E., Ferliyanti, F., Kuspradini, H., Dungani, R., \& Aditiawati, P. (2020). Chemical content in Two Teak Woods (Tectona grandis Linn. F.) that has been used for 2 years and 60 years. Journal of Biological Science, Technology and Management, 2(1), 15-19.

Roshetko, J., Perdana, A., Sabastian, G., Rohadi, D., Pramono, A., Widyani, N., . . Kusumowardhani, N. (2016). Smallholder Teak Production in Indonesia. Teaknet Bulletin, 9(3), 2-8. 
Salazar, C. (2016). Proyecto de cultivo de teca y el plan reforesta. Master's thesis, Universidad de Guayaquil, Facultad de Ciencias Económicas, Guayaquil.

Sarría, Y., Hernandez, P., \& Aguilera, E. (2009). Aplicación Del Análisis Estructural Para El Estudio Del Ordenamiento Territorial En El Sistema De Infraestructura Técnica, Caso De Estudio. Revista OIDLES, 3(7).

Suwannapinant, W. (2001). Silvicultural Systems. Bangkok: Kasetsart University.

Torres, L. (1982). Influencia del sitio y la expesura en el crecimiento de plantaciones de teca (Tectona grandis) en Caparo. Mérida: Universidad de los Andes.

Velasteguí, T., Gutiérrez, R., \& Guerrero, F. (2010). Plagas y enfermedades en plantaciones de Teca (Tectona grandis LF) en la zona de Balzar, Provincia del Guayas. Revista Ciencia y Tecnología, 3(1), 15-22.

Villacis, J. (2019). Evaluación de la germinación y crecimiento de Teca (Tectona grandis) de cuatro fuentes semilleras. Honduras: Zamorano: Escuela Agrícola Panamericana.

Walters, P., \& Lyons, K. (2016). Community teak forestry in Solomon Islands as donor development: when science meets culture. Land Use Policy, 57(30), 730-738.

Esta obra está bajo una Licencia Creative Commons Attribución-NoCommercial 4.0 International

\section{(cc) EY-NC}

